\title{
Progress of White Rot on Garlic Cultivars Planted at Different Times
}

Cleide M. F. Pinto, EMBRAPA/EPAMIG/CRZM, 36570-000, Viçosa, MG, Brazil; Luiz A. Maffia, Universidade Federal de Viçosa, Departmento de Fitopatologia, 36571-000, Viçosa, MG, Brazil; Richard D. Berger, University of Florida, Department of Plant Pathology, Gainesville 32611; Eduardo S. G. Mizubuti, Universidade Federal de Viçosa, Departmento de Fitopatologia; and Vicente W. D. Casali, Universidade Federal de Viçosa, Departmento de Fitotecnia

\section{ABSTRACT}

Pinto, C. M. F., Maffia, L. A., Berger, R. D., Mizubuti, E. S. G., and Casali, V. W. D. 1998. Progress of white rot on garlic cultivars planted at different times. Plant Dis. 82:1142-1146.

In the region of Amarantina, Minas Gerais state, Brazil, four annual experiments with garlic (Allium sativum) were established in fields infested with Sclerotium cepivorum, causal agent of garlic white rot, to investigate the effect of time of planting on the day when disease was first noticed $\left(t_{\text {onset }}\right)$, incidence at harvest $\left(y_{\mathrm{f}}\right)$, duration of epidemics $\left(t_{\mathrm{f}}-t_{\text {onset }}\right)$, and the response of five cultivars to white rot. Most epidemiological parameters were similar among cultivars. In 1986 to 1988 , no white rot was observed on garlic planted during the warm temperatures in January. The average onset of white rot occurred at different times dependent on the day of planting as average temperatures decreased from January to May. That is, for February plantings, onset occurred after 93 to 140 days (between 1 June and 5 July); for March plantings, about 90 days (15 to 28 June); for mid-April plantings, about 77 days (1 July); and mid-May plantings, about 66 days ( 20 July). Because of these different times of onset, the average duration of epidemics was shorter for crops planted in February (30 days) compared to crops planted in March (48 days) or April to May (54 to 69 days). In general, most disease (highest incidence and longest duration) occurred on crops planted in March to May. Therefore, severe losses to white rot would be expected when garlic is planted at the traditional times (March and April) in areas infested with sclerotia of S. cepivorum. The early planting of garlic is recommended as an important management strategy to avoid white rot in areas with these infested soils.

White rot, caused by Sclerotium cepivorum, was first associated with onion (Allium cepa) in the United Kingdom in 1841 and with garlic (Allium sativum) in Italy in 1903. Since these early reports, the disease has spread throughout the world (12). In Brazil, white rot has been found in most of the states in which garlic is grown. White rot is the most important disease of garlic in the state of Minas Gerais (MG) and $100 \%$ loss has been reported in some places.

The control of diseases caused by soilborne plant pathogens which produce sclerotia, such as $S$. cepivorum, has been very difficult, in both technical and economical aspects. The longevity of sclerotia in the soil, the potential to infect the host over long periods of time, and the location of infection sites under the soil surface are among the most important limitations for control $(10,21)$. Since sclerotia can survive in the soil for years, crop rotation is not effective as a control method $(4,9)$. If the initial population of sclerotia is high, the

Corresponding author: Luiz A. Maffia

E-mail: lamaffia@mail.ufv.br

Accepted for publication 26 June 1998.

Publication no. D-1998-0807-01R

(C) 1998 The American Phytopathological Society proportion of surviving sclerotia may be enough to cause severe epidemics even after solarization (10,27). Antagonistic microorganisms to $S$. cepivorum effective in vitro frequently are not efficient under field conditions $(11,20,26,32)$. Until now, resistance to $S$. cepivorum is not known in the genus Allium $(3,5,11,15)$, although there is some evidence that resistance may be found in onion $(32,35)$. Chemical control of $S$. cepivorum, as for other fungi which produce sclerotia, is very difficult $(11,33,34)$. In most cases, chemical control is not economically feasible, because of the high dosages of fungicides that are required. Under such conditions, pathogen resistance may be induced to some fungicides. The grower is then forced to use stronger fungicides, which may be toxic, may leave residues in food, and may cause environmental pollution and biological imbalance. Therefore, alternatives to manage this disease are needed to reduce the excessive use of chemical products in agriculture (2).

Temperature is one of the environmental factors which is critical for germination of sclerotia and growth of $S$. cepivorum. Therefore, temperature may affect the progress of white rot in the field $(1,10,13,19)$. Crowe and Hall (8) found that sclerotial germination was confined to temperatures between 9 and $24^{\circ} \mathrm{C}$ (optimum at $18^{\circ} \mathrm{C}$ ) and disease developed more rapidly with increasing temperature within a range of 6 to $24^{\circ} \mathrm{C}$. In this paper, the progress of white rot was studied under different planting times to determine if the incidence of white rot could be reduced by early (warmer) or late (cooler than traditional) planting times.

\section{MATERIALS AND METHODS}

Four field experiments were conducted in 1986 to 1988 and 1991 in the traditional garlic-production region of Amarantina, Ouro Preto, MG, Brazil. The experiments were set in a commercial field naturally infested with sclerotia of $S$. cepivorum, located at $1,147 \mathrm{~m}$ altitude, $20^{\circ} 23^{\prime} \mathrm{S}$ latitude, and $43^{\circ} 30^{\prime} \mathrm{W}$ longitude. The annual weather averages were: air temperature $18.5^{\circ} \mathrm{C}$, relative humidity $82 \%$, and precipitation $1,670 \mathrm{~mm}$. Air temperature for all experiments, and soil temperature for 1991, were recorded (Fig. 1). The farm where the experiments were conducted had been cropped with garlic in the previous 4 years, with losses due to white rot of $100 \%$ in each of the previous 2 years.

Soil was sampled for $S$. cepivorum and nutrients before experiments were established. Sclerotia were extracted by a modification and combination of the techniques of Crowe et al. (9), Resende and Zambolim (28), and Vimard et al. (36), and counted. For 1986, 1987, 1988, and 1991, the average \pm standard deviation of the number of sclerotia were $30 \pm 25,57 \pm 40,31 \pm 30$, and $14 \pm 6$ per $100 \mathrm{~g}$ dried soil, respectively. The soil samples were also chemically analyzed in each experiment. The $\mathrm{pH}$ ranged from 6.2 to $6.4, \mathrm{Al}^{+++}\left(\mathrm{cmol}_{\mathrm{c}} \mathrm{kg}^{-1}\right)$ was zero, $\mathrm{Ca}^{++}\left(\mathrm{cmol}_{\mathrm{c}} \mathrm{kg}^{-1}\right)$ ranged from 0.7 to $4.0, \mathrm{Mg}^{++}\left(\mathrm{cmol}_{\mathrm{c}} \mathrm{kg}^{-1}\right)$ was $1.2, \mathrm{P}$ (ppm) ranged from 124.0 to 152.3 , and $\mathrm{K}$ (ppm) ranged from 85.0 to 130.0 . The soil was classified as loamy sand based on the granulometric analysis.

In each year from 1986 to 1988 , a splitplot design was used, with planting times as main plots and cultivars as subplots. In each experimental plot, treatments were arranged as randomized blocks with five replications of main plots and subplots. In 1986 and 1987, the three main plots were planted on the 28th day of January, February, and March. In 1988, the planting dates were the 15th day of January, February, and March. The subplots were the cultivars Amarante, Cateto Roxo, Chinês, and 
Peruano. In 1991, the statistical design was a 4 by 3 factorial in randomized blocks, with five replications. Treatments were four planting times (15 February, 15 March, 15 April, and 15 May) and three cultivars (Amarante, Cateto Roxo, and Centenário). March and April were chosen to represent standard conditions, since plantings in commercial fields in Minas Gerais are concentrated during those months. January and February plantings were considered early and the May planting late.

Each subplot in 1986 to 1988 and each plot in 1991 was a bed $2.0 \mathrm{~m}$ long and 0.9 $\mathrm{m}$ wide with three rows of plants. The beds were fertilized before planting with 4-14-8 (N-P-K), plus magnesium sulfate, zinc sulfate, and borax, at 1,500, 50, 15, and 5 $\mathrm{kg} / \mathrm{ha}$, respectively. Spacing was $0.3 \mathrm{~m}$ between rows and $0.1 \mathrm{~m}$ between cloves in the rows; therefore, 60 cloves were planted in each bed. Cloves for planting were selected on the appropriate sieve, and those with medium size (held on the mesh of 8 by $17 \mathrm{~mm}$, weighing approximately $2 \mathrm{~g}$ ) were used. The cloves were hand-planted with the apex up and covered with a fine layer of soil. During the culture cycle, hand-weeding and sprays to control insects and diseases on the leaves were performed as necessary. Irrigation was by flooding and was stopped at maturity when plants were yellow and the oldest leaves were dry. The initial stand (total of germinated plants in each plot) was determined 60 days after planting in 1986 to 1988 and 30 days after planting in 1991.

During the season, disease incidence (diseased plants as the percentage of initial stand) was evaluated for each plot. A plant was considered diseased if it had typical symptoms of white rot (yellowing, wilt) and mycelium or sclerotia were seen

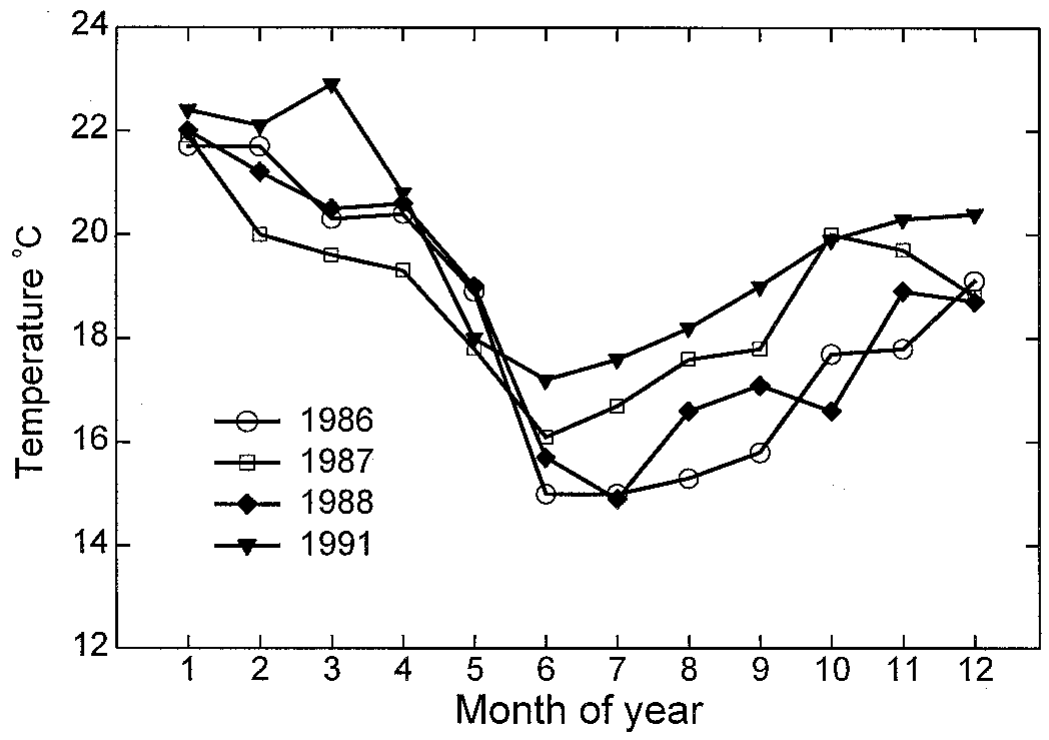

Fig. 1. Monthly average of mean air temperature ([maximum + minimum $] / 2)$ during the years of the experiments. around the base of the plant, in the soil, or on the bulbs. Disease incidence was evaluated at intervals of 30 days in 1986 to 1988, and at intervals of 15 days in 1991. Cumulative curves of disease progress were drawn for each combination of planting time $\times$ cultivar. Other epidemiological components evaluated were time of first observation of disease $\left(t_{\text {onset }}\right)$, observation of incidence at harvest $\left(y_{\mathrm{f}}\right)$, and duration of epidemics $\left(t_{\mathrm{f}}-t_{\text {onset }}\right)$. The harvest times varied from 120 to 165 days depending on cultivar and season. Data were subjected to the analysis of variance and Tukey test to determine differences among means.

\section{RESULTS}

In the four experiments, an interaction $(P=0.05)$ between cultivars and planting times was noticed for all epidemiological components studied (Tables 1 to 3 ). Air temperature was recorded for the 4 years (Fig. 1). Soil temperature, averaged only for February, March, April, May, June, and July 1991 was $22.6,22.4,21.5,20.1,19.9$, and $18.2^{\circ} \mathrm{C}$, respectively.

Onset of white rot. In 1986 to 1988, no white rot was observed on garlic planted in January (there was no planting in January 1991). For plantings made in February, the first occurrence of white rot was observed from 90 to 150 days (mean 118 days) after planting (i.e., between 1 June and 5 July; Table 1). For plantings made in March, white rot was observed sooner, from 90 to 96 days (mean 92 days) after planting (i.e., between 13 to 28 June). In 1991, white rot was first observed from 69 to 81 days after planting in April (around 1 July) and from 60 to 75 days after planting in May (around 20 July).

Disease progress. For the first 2 to 3 weeks after white rot was initially observed in a crop, the disease progress was exponential. After this period, the disease progress was mostly linear at 0.9 to $2.5 \%$ day $^{-1}$ (Fig. 2).

Table 1. Days after planting for onset of white rot on garlic cultivars planted at different times ${ }^{\mathrm{x}}$

\begin{tabular}{|c|c|c|c|c|c|c|c|}
\hline \multirow[b]{2}{*}{ Year } & \multirow[b]{2}{*}{ Planting day } & \multicolumn{5}{|c|}{ Cultivar } & \multirow[b]{2}{*}{ Average for time } \\
\hline & & Amarante & Cateto Roxo & Chinês & Peruano & Centenário & \\
\hline \multirow{3}{*}{1986} & 28 January &..$^{\mathrm{y}}$ & & & & $\mathrm{NT}^{\mathrm{z}}$ & \\
\hline & 28 February & $102 \mathrm{Aa}$ & $123 \mathrm{Aa}$ & $117 \mathrm{Aa}$ & $102 \mathrm{Aa}$ & NT & 111 \\
\hline & $28 \mathrm{March}$ & $90 \mathrm{Ab}$ & $90 \mathrm{Ab}$ & $90 \mathrm{Ab}$ & $96 \mathrm{Aa}$ & NT & 92 \\
\hline \multirow[t]{3}{*}{1987} & 28 January & $\ldots$ & $\ldots$ & 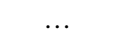 & $\ldots$ & NT & $\ldots$ \\
\hline & 28 February & $90 \mathrm{Ba}$ & $90 \mathrm{Ba}$ & $90 \mathrm{Ba}$ & $102 \mathrm{Aa}$ & NT & 93 \\
\hline & $28 \mathrm{March}$ & $90 \mathrm{Aa}$ & $90 \mathrm{Aa}$ & $90 \mathrm{Aa}$ & $90 \mathrm{Ab}$ & NT & 90 \\
\hline \multirow[t]{3}{*}{1988} & 15 January & & $\ldots$ & $\ldots$ & $\ldots$ & NT & $\ldots$ \\
\hline & 15 February & 130 & 150 & 150 & 120 & NT & 138 \\
\hline & 15 March & 90 & 90 & 90 & 90 & NT & 90 \\
\hline \multirow[t]{4}{*}{1991} & 15 February & $120 \mathrm{Aa}$ & $133 \mathrm{Aa}$ & NT & NT & $135 \mathrm{Aa}$ & 129 \\
\hline & 15 March & $96 \mathrm{Ab}$ & $90 \mathrm{Ab}$ & NT & NT & $96 \mathrm{Abc}$ & 94 \\
\hline & 15 April & $69 \mathrm{Ac}$ & $81 \mathrm{Ab}$ & NT & NT & $81 \mathrm{Ac}$ & 77 \\
\hline & 15 May & $63 \mathrm{Ac}$ & $60 \mathrm{Ac}$ & NT & NT & $75 \mathrm{Ac}$ & 66 \\
\hline Average for cultivar & & 94 & 100 & 95 & 96 & 97 & \\
\hline
\end{tabular}

\footnotetext{
${ }^{\mathrm{x}}$ For each year, means of cultivars with the same capital letter in each row and means of planting date with small letters in each column do not differ, according to Tukey test $(P=0.05)$.

y $\ldots=$ disease was not detected.

${ }^{\mathrm{z}} \mathrm{NT}=$ cultivar not tested.
} 
Duration of the epidemics. Because of the different times of onset, the duration of the epidemics varied for the several crops (Table 2). In the crops planted in February, the duration ranged from 12 to 60 days (mean 30 days). For crops planted in March, the duration was longer, from 30 to 69 days (mean 48 days). For 1991, the duration of the epidemics were 39 to 69 days (mean 54 days) in April and 60 to 75 days (mean 69 days) in May. Among the cultivars, the shortest mean duration was with Chinês (24 days), followed by Peruano (26 days), Cateto Roxo (38 days), Amarante (42 days), and Centenário (57 days). This ranking of cultivars was the same ranking for length of the crop cycle, with Chinês having the shortest cycle.

Incidence of white rot at harvest. No bulbs with white rot were found at harvest from crops planted in January (Table 3). For crops planted in February, the incidence at harvest ranged from 2 to $91 \%$ (mean 35\%), depending on year of planting. For March plantings, the range was 59 to $100 \%$ (mean $88 \%$ ). In 1991, the crops planted in April averaged 68\% and for May they averaged $72 \%$ incidence of white rot at harvest.

In 1986, 1987, and 1991, there was a significant $(P=0.05)$ difference among cultivars for incidence of white rot at harvest for certain times of planting. However, there was no common trend among cultivars. Chinês had the lowest incidence $(29 \%)$ for crops planted in February 1986; the other three cultivars had 41 to $54 \%$ of the bulbs with white rot. For the February planting in 1987, Peruano had the lowest incidence (25\%), whereas 74 to $91 \%$ white rot occurred in the other three cultivars. For the planting in February 1991, Amarante and Cateto Roxo had low incidences (9 to $12 \%$ ) of white rot compared to Centenário (52\%). Averaged over all times of planting, and over all years, Cateto Roxo, Amarante, Chinês, and Peruano averaged 41 to $48 \%$ incidence of white rot at harvest. Centenário averaged $71 \%$ incidence of white rot over the four planting times in 1991.

\section{DISCUSSION}

During the 4 years of field experiments, the first symptoms of white rot were always observed 60 days or later after planting. This 2-month delay occurred although the area was naturally infested with sclerotia of $S$. cepivorum and the temperature, at least in the late plantings, was always favorable for sclerotial germination and fungal growth. According to Entwistle (11), plants of Allium spp. can be infected by the pathogen in any developmental stage when environmental conditions are favorable for the fungus. However, the type of symptom and the severity of disease depend on the stage of host development and duration of soil conditions, primarily temperature, favorable to the pathogen. The greatest germination of sclerotia and infection of hosts in more developed plants are probably because of the more developed root system and, consequently, larger production of exudates, assuming that temperature is favorable.

The first disease symptoms always coincided with the period of bulbification of

Table 2. Duration of white rot epidemics on garlic cultivars planted at different times ${ }^{\mathrm{y}}$

\begin{tabular}{|c|c|c|c|c|c|c|c|}
\hline \multirow[b]{2}{*}{ Year } & \multirow[b]{2}{*}{ Planting day } & \multicolumn{5}{|c|}{ Cultivar } & \multirow[b]{2}{*}{ Average for time } \\
\hline & & Amarante & Cateto Roxo & Chinês & Peruano & Centenário & \\
\hline \multirow[t]{3}{*}{1986} & 28 January & $0 \mathrm{Ac}$ & $0 \mathrm{Ac}$ & $0 \mathrm{Ac}$ & $0 \mathrm{Ab}$ & $\mathrm{NT}^{\mathrm{z}}$ & 0 \\
\hline & 28 February & $33 \mathrm{Ab}$ & $12 \mathrm{Ab}$ & $18 \mathrm{Ab}$ & $33 \mathrm{Aa}$ & NT & 24 \\
\hline & $28 \mathrm{March}$ & $45 \mathrm{Aa}$ & $45 \mathrm{Aa}$ & $45 \mathrm{Aa}$ & $39 \mathrm{Aa}$ & NT & 43 \\
\hline \multirow[t]{3}{*}{1987} & 28 January & $0 \mathrm{Ac}$ & $0 \mathrm{Ac}$ & $0 \mathrm{Ac}$ & $0 \mathrm{Ac}$ & NT & 0 \\
\hline & 28 February & $60 \mathrm{Aa}$ & $60 \mathrm{Aa}$ & $60 \mathrm{Aa}$ & $33 \mathrm{Bb}$ & NT & 53 \\
\hline & $28 \mathrm{March}$ & $30 \mathrm{Bb}$ & $30 \mathrm{Bb}$ & $30 \mathrm{Bb}$ & $60 \mathrm{Aa}$ & NT & 38 \\
\hline \multirow[t]{3}{*}{1988} & 15 January & $0 \mathrm{Ac}$ & $0 \mathrm{Ac}$ & $0 \mathrm{Ac}$ & $0 \mathrm{Ac}$ & NT & 0 \\
\hline & 15 February & $12 \mathrm{Ab}$ & $12 \mathrm{Ab}$ & $12 \mathrm{Ab}$ & $12 \mathrm{Ab}$ & NT & 12 \\
\hline & 15 March & $60 \mathrm{Aa}$ & $60 \mathrm{Aa}$ & $60 \mathrm{Aa}$ & $60 \mathrm{Aa}$ & NT & 60 \\
\hline \multirow[t]{4}{*}{1991} & 15 February & $12 \mathrm{Bd}$ & $12 \mathrm{Bc}$ & NT & NT & $30 \mathrm{Ab}$ & 14 \\
\hline & 15 March & $39 \mathrm{Bc}$ & $45 \mathrm{Bb}$ & NT & NT & $69 \mathrm{Aa}$ & 51 \\
\hline & 15 April & $54 \mathrm{Bb}$ & $39 \mathrm{Cb}$ & NT & NT & $69 \mathrm{Aa}$ & 54 \\
\hline \multirow{2}{*}{\multicolumn{2}{|c|}{ Average for cultivar }} & $72 \mathrm{Aa}$ & $75 \mathrm{Aa}$ & NT & NT & $60 \mathrm{Ba}$ & 69 \\
\hline & & 42 & 38 & 24 & 26 & 57 & \\
\hline
\end{tabular}

${ }^{\mathrm{y}}$ For each year, means of cultivars with the same capital letter in each row and means of planting date with small letters in each column do not differ, according to Tukey test $(P=0.05)$.

z NT = cultivar not tested.

Table 3. Incidence of white rot at harvest on garlic cultivars planted at different times ${ }^{\mathrm{y}}$

\begin{tabular}{|c|c|c|c|c|c|c|c|}
\hline \multirow[b]{2}{*}{ Year } & \multirow[b]{2}{*}{ Planting day } & \multicolumn{5}{|c|}{ Cultivar } & \multirow[b]{2}{*}{ Average for time } \\
\hline & & Amarante & Cateto Roxo & Chinês & Peruano & Centenário & \\
\hline \multirow[t]{3}{*}{1986} & 28 January & $0 \mathrm{Ac}$ & $0 \mathrm{Ab}$ & $0 \mathrm{Ac}$ & $0 \mathrm{Ac}$ & $\mathrm{NT}^{\mathrm{z}}$ & 0 \\
\hline & 28 February & $41 \mathrm{ABb}$ & $0 \mathrm{Cb}$ & $29 \mathrm{Bb}$ & $54 \mathrm{Ab}$ & NT & 44 \\
\hline & $28 \mathrm{March}$ & $91 \mathrm{Aa}$ & $88 \mathrm{Aa}$ & $87 \mathrm{Aa}$ & $94 \mathrm{Aa}$ & NT & 90 \\
\hline \multirow[t]{3}{*}{1987} & 28 January & $0 \mathrm{Ac}$ & $0 \mathrm{Ac}$ & $0 \mathrm{Ab}$ & $0 \mathrm{Ac}$ & NT & 0 \\
\hline & 28 February & $84 \mathrm{ABb}$ & $74 \mathrm{Bb}$ & $91 \mathrm{Aa}$ & $25 \mathrm{Cb}$ & NT & 69 \\
\hline & $28 \mathrm{March}$ & $100 \mathrm{Aa}$ & $100 \mathrm{Aa}$ & $100 \mathrm{Aa}$ & $91 \mathrm{Aa}$ & NT & 98 \\
\hline \multirow[t]{3}{*}{1988} & 15 January & $0 \mathrm{Ab}$ & $0 \mathrm{Ab}$ & $0 \mathrm{Ab}$ & $0 \mathrm{Ab}$ & NT & 0 \\
\hline & 15 February & $2 \mathrm{Ab}$ & $4 \mathrm{Ab}$ & $5 \mathrm{Ab}$ & $3 \mathrm{Ab}$ & NT & 4 \\
\hline & 15 March & $93 \mathrm{Aa}$ & 96 Аа & 97 Аa & $97 \mathrm{Aa}$ & NT & 96 \\
\hline \multirow[t]{4}{*}{1991} & 15 February & $9 \mathrm{Bb}$ & $12 \mathrm{Bb}$ & NT & NT & $52 \mathrm{Ab}$ & 25 \\
\hline & $15 \mathrm{March}$ & $68 \mathrm{ABa}$ & $59 \mathrm{Ba}$ & NT & NT & $81 \mathrm{Aa}$ & 69 \\
\hline & 15 April & $67 \mathrm{Aa}$ & $61 \mathrm{Aa}$ & NT & NT & $74 \mathrm{Aab}$ & 68 \\
\hline & 15 May & $67 \mathrm{Aa}$ & $74 \mathrm{Aa}$ & NT & NT & $75 \mathrm{Aab}$ & 72 \\
\hline Average for cultivar & & 48 & 48 & 46 & 40 & 69 & \\
\hline
\end{tabular}

y For each year, means of cultivars with the same capital letter in each row and means of planting date with small letters in each column do not differ, according to Tukey test $(P=0.05)$.

z NT = cultivar not tested . 
garlic. The relation between diameter of neck or pseudostem and diameter of the bulb (bulbar ratio) is used to quantify bulb development $(6,24,31)$. Values of bulbar ratio around $0.5,0.2$, and 0.1 to 0.2 indicate the beginning of bulb development, closeness to ripening, and ripening, respectively. The bulbar ratio on Lavínia, Amarante, Cateto Roxo, and Mineiro increased until 60 days after planting and then decreased until complete ripening of garlic; it was 0.5 in Cateto Roxo and Mineiro by 100 days and Lavínia and Amarante by 115 days (16). Couto (7) observed a bulbar ratio of 0.6 at 55 days after planting and 0.4 at 87 days for Mineiro. Fontes (17) reported for Amarante that the bulbar ratio varied from 0.68 to 0.74 after 60 days, and decreased to 0.20 to 0.40 after 150 days. Therefore, bulbification usually starts by 60 days after planting (17). Precursors of flavor and odor in Allium spp., non-volatile sulfur compounds (18), are reported to be synthesized in leaves and translocated to clove scales which store them (23). Bulb content of these precursors increases during bulbification and gradually decreases with ripening (22). Germination of sclerotia is activated by root exudation of these compounds. Symptoms of white rot usually begin 60 days after planting, which coincides with the production and liberation of those exudates and with soil temperature that is favorable for sclerotial germination and mycelial growth. Thus, it was impossible to separate which component, bulbification or temperature, was most responsible for the infection of garlic plants.

Temperatures favorable for sclerotial germination and mycelial growth of $S$. cepivorum are between 10 and $20^{\circ} \mathrm{C}$, and the optimum is $15^{\circ} \mathrm{C}$ in the presence of Allium exudates or extracts $(1,13)$. Crowe and Hall (8) found that sclerotial germination was between 9 and $24^{\circ} \mathrm{C}$ (optimum at $18^{\circ} \mathrm{C}$ ); however, germination in soil was five times more efficient in the presence of garlic extract. The average soil temperatures were between 20 and $22.6^{\circ} \mathrm{C}$ during the whole season in 1991 and these temperatures apparently were favorable for fungal development, infection, and disease progress at normal (cooler) times of garlic planting.

White rot was not observed in garlic planted in January, which probably was due to temperatures too warm for the development of the fungus during bulbification. The temperatures favorable for the fungus occurred when plants from the January planting were close to ripening and production of exudates presumably was reduced (22).

Disease symptoms were observed only after 90 days after planting in February. This probably was due to the concurrence of favorable temperatures for the fungus with the production of exudates by the host, which usually starts by 60 days after planting. Bulbification can start later, as Fontes (17) observed a bulb ratio of 0.5 for Amarante at 100 days and for Cateto Roxo at 115 days after planting. High levels of disease incidence (44 to 69\%) were observed for the plantings on 28 February in 1986 and 1987, which was in contrast to the lower incidences for the plantings on 15 February in 1988 and 1991. The later planting by 2 weeks in 1986 and 1987 resulted in the crop being exposed to cooler, more favorable environmental conditions; therefore, a higher incidence of white rot resulted.

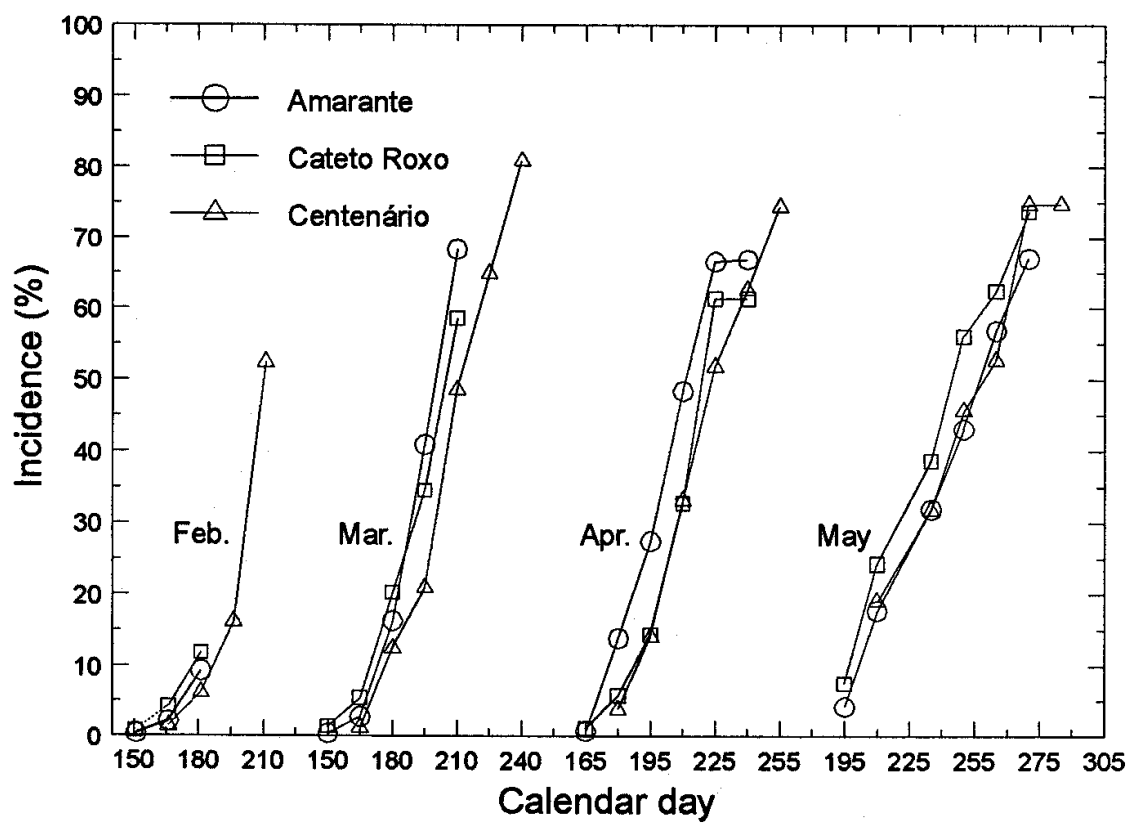

Fig. 2. Disease progress curves for the incidence of white rot on three garlic cultivars planted on the 15th of each designated month in 1991.
Disease onset after 75 days for the March plantings probably was due to cooler temperatures favorable for the fungus and bulbification of garlic. This concurrence also may have induced an early onset of the disease for the plantings in April and May in 1991. Temperatures were favorable for the fungus during the whole season of these latter crops but the first symptoms were only observed 60 days after planting.

The bulbification of garlic depends on photoperiod (25), with greater bulbification occurring during shorter days. In 1991, Amarante and Cateto Roxo were planted in April and May (shorter photoperiods than in January or February) and received enough stimulus to bulbify earlier than at the other planting times. Therefore, root exudates, which stimulate sclerotial germination, were produced earlier and symptoms developed sooner, considering that temperature was always favorable for sclerotial germination and infection. Since the bulbification of Centenário is somewhat later, disease onset on this cultivar usually was observed later after planting than for the other two cultivars.

Although disease incidence was different among the garlic cultivars, no inference can be made regarding host resistance. The ranking of cultivars changed among experiments and resistance in garlic to white rot is unknown. The reaction of Allium spp. and onion cultivars to $S$. cepivorum depends on the quantity and quality of stimulatory compounds they produce $(10,14,15)$.

In the February planting of 1987, a lower incidence of white rot was observed on Peruano compared to the other cultivars. This lower value could be from the greater distances among plants, because of the reduced stand that occurred with this cultivar. Growers used to plant Peruano because it can be conserved longer, but it has a long dormancy (30), which may have led to the low stand. Scott (29) reported that with greater distance among plants, secondary infection was reduced because of the lower chance of mycelium reaching the neighboring plants.

Plantings in the cooler months of March, April, and May had higher incidences of white rot than plantings in the warmer months of January and February. At the later planting times, the close relationship of favorable temperature to the fungus and garlic bulbification may have provided earlier and faster rates of disease progress and higher final incidences than plantings in the first half of February. Therefore, garlic planting before the end of February should be considered for the management of white rot under Brazilian conditions. This strategy of planting time should also be evaluated in other regions of the world, where white rot is threatening garlic production and other control strategies have failed. 


\section{LITERATURE CITED}

1. Adams, P. B. 1987. Effects of soil temperature, moisture, and depth on survival and activity of Sclerotinia minor, Sclerotium cepivorum, and Sporidesmium sclerotivorum. Plant Dis. 71:170-174.

2. Azevedo, J. L. 1991. Melhoramento genético e preservação de fungos utilizados no controle biológico de doenças de plantas. Pages 237251 in: Controle Biológico de Doenças de Plantas. W. Bettiol, ed. Jaguariúna. EMBRAPA-CNPDA. Documentos 15.

3. Brix, H. D., and Zinkernagel, V. 1992. Screening for resistance of Allium species to Sclerotium cepivorum with special reference to non-stimulatory resistance. Plant Pathol. 41:308-316.

4. Coley-Smith, J. R. 1990. White rot disease of Allium: problems of soil-borne disease in microcosm. Plant Pathol. 39:214-222.

5. Coley-Smith, J. R., and Entwistle, A. R. 1988. Susceptibility of cultivars of garlic to Sclerotium cepivorum. Plant Pathol. 37:261264.

6. Couto, F. A. A. 1958. Resultados experimentais de seleção e métodos de plantio de bulbilhos na brotação, crescimento e produção de alho. M.S. thesis. Viçosa, Universidade Rural do Estado de Minas Gerais.

7. Couto, F. A. A. 1961. Efeito do tipo de cloveho na brotação, crescimento e produção de alho. Experientiae 1:247-280.

8. Crowe, F. J., and Hall, D. H. 1980. Soil temperature and moisture effects on sclerotium germination and infection of onion seedlings by Sclerotium cepivorum. Phytopathology 70:74-78.

9. Crowe, F. J., Hall, D. H., Greathead, A. S., and Baghott, K. G. 1980. Inoculum density of Sclerotium cepivorum and the incidence of white rot of onion and garlic. Phytopathology 70:64-69.

10. Entwistle, A. R. 1990. Allium white rot and its control. Soil Use Manage. 6:201-209.

11. Entwistle, A. R. 1990. Root diseases. Pages 103-154 in: Onions and Allied Crops, Vol. 2. H. D. Rabinowitch and J. L. Brewster, eds. C.R.C., Boca Raton, FL.

12. Entwistle, A. R., and Mattusch, P., eds. 1990. Proc. Fourth Int. Workshop on Allium White Rot, Neustadt/Weinstrasse, Federal Republic of Germany.

13. Entwistle, A. R., and Munasinghe, H. L.
1978. Epidemiology and control of white rot disease of onions. Pages 187-191 in: Plant Disease Epidemiology. P. R. Scott and A. Bainbridge, eds. Blackwell Scientific Pub., Oxford.

14. Esler, G., and Coley-Smith, J. R. 1983. Flavor and odor characteristics of species of Allium in relation to their capacity to stimulate germination of sclerotia of Sclerotium cepivorum. Plant Pathol. 32:13-22.

15. Esler, G., and Coley-Smith, J. R. 1984. Resistance to Sclerotium cepivorum in Allium and other genera. Plant Pathol. 33:199-204.

16. Ferreira, F. A. 1972. Análise do Crescimento de Quatro Cultivares de Alho (Allium sativum L.). MS thesis, Universidade Federal de Viçosa, MG, Brasil.

17. Fontes, P. C. R. 1973. Efeitos de Cinco Épocas de Plantio sobre o Crescimento e Produção de Alho (Allium sativum L.) Cultivar Amarante. MS thesis, Universidade Federal de Viçosa, MG, Brasil.

18. Freeman, G. G., and Whenham, R. J. 1975. The use of synthetic (+)-S-1-propyl-L-cysteine sulphoxide and of alliinase preparations in studies of flavour changes resulting from processing of onion (Allium cepa L.). J. Sci. Food Agric. 26:1333-1346.

19. Gerbrandy, S. J.-.J. 1989. The effects of various temperatures during storage in soil on subsequent germination of sclerotia of Sclerotium cepivorum. Neth. J. Plant Pathol. 95:319-326.

20. Ghaffar, A. 1969. Biological control of white rot of onion. I. Interactions of soil micro-organisms with Sclerotium cepivorum Berk. Mycopathol. Mycol. Appl. 38:101-111.

21. Ghini, R. 1991. Integração do controle biológico com outros métodos de controle de doenças de plantas. Pages 201-217 in: Bettiol, W. (coord.). Controle biológico de doenças de plantas. Jaguariúna: EMBRAPA-CNPDA. Documentos 15.

22. Lancaster, J. E., McCallion, B. J., and Shaw, M. L.1984. The levels of S-alk(en)yl-L-cysteine sulphoxides, during the growth of the onion (Allium cepa L). J. Sci. Food Agric. 35:415-420.

23. Lancaster, J. E., McCallion, B. J., and Shaw, M. L. 1986. The dynamics of the flavour precursors, the S-alk(en)yl-L-cysteine sulphoxides, during leaf blade and scale development in the onion (Allium cepa). Physiol. Plant.
66:293-297.

24. Mann, L. K. 1952. Anatomy of the garlic bulb and factors affecting bulb development. Hilgardia 21:195-251.

25. Mann, L. K., and Minges, P. 1958. Growth and bulbing of garlic (Allium sativum L.) in response to storage temperature of planting stocks, day length and planting date. Hilgardia 27:385-41.

26. Oliveira, V. L., Bellei, M. M., and Borges, A. C. 1984. Control of white rot of garlic by antagonistic fungi under controlled environmental conditions. Can. J. Microbiol. 30:884889.

27. Porter, I. J., and Merriman, P. R. 1983. Effects of solarization of soil on nematode and funga pathogens at two sites in Victoria. Soil Biol. Biochem. 15:39-44

28. Resende, M. L. V., and Zambolim, L. 1986 Eficiência de métodos utilizados para quantificação da população de escleródios de Sclerotium cepivorum Berk. no solo. Fitopatol. Bras. 11:493-500.

29. Scott, M. R. 1956. Studies of the biology of Sclerotium cepivorum Berk. II. The spread of white rot from plant to plant. Ann. Appl. Biol. 44:584-589.

30. Silva, N. F. 1986. O alho Peruano, uma perspectiva. Inf. Agropecuário 12 (142): 11

31. Silva, N. F., Oliveira, G. D., Vasconcelos, E. F. C., and Haag, H. P. 1970. Nutrição mineral de hortaliças: XI-Absorção de nutrientes pela cultura do alho. O Solo 62:7-17.

32. Utkhede, R. S., and Rahe, J. E. 1978. Screening world onion germplasm collection for resistance to white rot. Can. J. Plant Sci. 58:819-822.

33. Utkhede, R. S., and Rahe, J. E. 1980. Biological control of onion white rot. Soil Biol. Biochem. 12:101-104.

34. Utkhede, R. S., and Rahe, J. E. 1983. Chemical and biological control of onion white rot in muck and mineral soils. Plant Dis. 67:153155.

35. Utkhede, R. S., Rahe, J. E., Coley-Smith, Q. P., Van der Meer, Q. P., Brewer, J. G., and Criscola, V. 1982. Genotype-environment interaction for resistance to onion white rot Can. J. Plant Pathol. 4:269-271.

36. Vimard, B., Leggett, M. E., and Rahe, J. E. 1986. Rapid isolation of sclerotia of Sclerotium cepivorum from muck soil by sucrose centrifugation. Phytopathology 76:465-467. 